\title{
Abundance, behavior, and movement patterns of western gray whales in relation to a 3-D seismic survey, Northeast Sakhalin Island, Russia
}

\author{
Glenn Gailey • Bernd Würsig • Trent L. McDonald
}

Received: 20 April 2006 / Accepted: 30 March 2007 / Published online: 7 July 2007

(C) Springer Science + Business Media B.V. 2007

\begin{abstract}
A geophysical seismic survey was conducted in the summer of 2001 off the northeastern coast of Sakhalin Island, Russia. The area of seismic exploration was immediately adjacent to the Piltun feeding grounds of the endangered western gray whale (Eschrichtius robustus). This study investigates relative abundance, behavior, and movement patterns of gray whales in relation to occurrence and proximity to the seismic survey by employing scan sampling, focal follow, and theodolite tracking methodologies. These data were analyzed in relation to temporal, environmental, and seismic related variables to evaluate potential disturbance reactions of gray whales to the seismic survey. The relative numbers of whales and pods recorded from five shore-based stations were not significantly different during periods when seismic surveys were occurring compared to periods when no seismic surveys were occurring and to the post-seismic period. Univariate analyses
\end{abstract}

G. Gailey $(\bowtie) \cdot$ B. Würsig

Marine Mammal Research Program,

Texas A\&M University at Galveston,

4700 Avenue U Building 303,

Galveston, TX 77551, USA

e-mail: gaileyg@tamug.edu

T. L. McDonald

Western EcoSystems Technology, Inc.,

2003 Central Avenue,

Cheyenne, WY 82001, USA indicated no significant statistical correlation between seismic survey variables and any of the eleven movement and behavior variables. Multiple regression analyses indicated that, after accounting for temporal and environmental variables, 6 of 11 movement and behavior variables (linearity, acceleration, mean direction, blows per surfacing, and surface-dive blow rate) were not significantly associated with seismic survey variables, and 5 of 11 variables (leg speed, reorientation rate, distancefrom-shore, blow interval, and dive time) were significantly associated with seismic survey variables. In summary, after accounting for environmental variables, no correlation was found between seismic survey variables and the linearity of whale movements, changes in whale swimming speed between theodolite fixes, mean direction of whale movement, mean number of whale exhalations per minute at the surface, mean time at the surface, and mean number of exhalations per minute during a whales surfaceto-dive cycle. In contrast, at higher received sound energy exposure levels, whales traveled faster, changed directions of movement less, were recorded further from shore, and stayed under water longer between respirations.

Keywords Abundance Behavior - Movement . Geophysical seismic survey · Western gray whale Eschrichtius robustus · Sakhalin Island · Russia 


\section{Introduction}

There are two extant genetically and geographically isolated populations of gray whales (Eschrichtius robustus): the eastern North Pacific and western North Pacific or Korean-Okhotsk gray whales (LeDuc et al. 2002; Weller et al. 2002a; Moore and Clarke 2003). Although the eastern North Pacific gray whales have recovered from commercial whaling (Buckland and Breiwick 2002), the western population, comprising only approximately $100-115$ individuals (Weller et al. 2004; Yakovlev and Tyurneva 2005), remains in danger of extinction. The small number of whales in combination with the possibility that there may be fewer than 50 reproductively active individuals was the basis for The World Conservation Union (IUCN) listing western gray whales as Critically Endangered (Hilton-Taylor 2000; Weller et al. 2002a).

In the summer of 2001, a 3-D geophysical seismic survey was conducted in near-shore waters off Sakhalin Island by Dalmorneftegas under contract to Exxon Neftegas Limited (ENL), the operator of the Sakhalin-1 consortium. That activity occurred during the summer foraging period of western gray whales in the Odoptu Seismic Survey Area located immediately offshore from the Piltun feeding grounds, one of two known feeding areas for western gray whales off northeastern Sakhalin Island, Russia. The exposure of western gray whales to sounds produced by seismic surveys raised concern about potential disturbance and possible displacement of whales out of important feeding habitat. The effects of marine seismic surveys on baleen whales have been documented for a number of species, such as bowhead whales (Reeves et al. 1984; Richardson et al. 1986, 1999; Ljungblad et al. 1988), humpback whales (McCauley et al. 1998, 2000), and gray whales (Malme and Miles 1985; Malme et al. 1986). Malme et al. (1986) found that $\sim 10 \%$ of eastern gray whales stopped feeding and moved away from an active seismic ship when received sound levels near the whales exceeded $163 \mathrm{~dB}$ re $1 \mu \mathrm{Pa}$ (rms). Richardson et al. (1995) summarized potential "zones" of avoidance and behavioral disturbance reactions of baleen whales in response to seismic surveys with received levels ranging between $150-170 \mathrm{~dB}$ re $1 \mu \mathrm{Pa}(\mathrm{rms})$.

The energy source for the Odoptu seismic survey consisted of an array of 28 airguns with a maximum potential volume of 3,090 in ${ }^{3}$. However, the full array and volume were only used during the calibration studies during 2-5 and 12-14 August. In area A, nearest to the gray whale feeding area, $54.4 \%$ of the seismic shots were at a volume of $90 \mathrm{in}^{3}$ (mainly during turns when airgun volume was reduced), $37.9 \%$ were at a volume of $1,640 \mathrm{in}^{3}$ (during seismic acquisition), and $2.4 \%$ were at a volume of 3,090 $\mathrm{in}^{3}$ (during the calibration study), with the remaining $5.3 \%$ shots at intermediate volumes (Rutenko et al. 2007).

Mitigation and monitoring programs were developed by ENL to minimize impacts of the seismic survey on western gray whales. The mitigation plan used $163 \mathrm{~dB}$ re $1 \mu \mathrm{Pa}$ (rms) as the received sound level threshold below which most feeding gray whales would not be affected. An acoustical calibration study was conducted prior to the seismic survey to evaluate characteristics of sound propagation in the study area (Rutenko et al. 2007). Hydrophones were deployed along the $20 \mathrm{~m}$ depth contour to record seismic sounds and determine when and approximately where the $163 \mathrm{~dB}$ re $1 \mu \mathrm{Pa}$ (rms) threshold was reached. Systematic aerial surveys in 1999 and 2000 indicated that most $(95 \%)$ of western gray whales were found inside the $20 \mathrm{~m}$ contour (Sobolevsky, 2000, 2001; Weller et al. 2002c). Based on this whale distribution information, and information from the acoustic calibration study, the size of the Odoptu seismic survey area was reduced by $19 \%$ to eliminate all areas inside the $20 \mathrm{~m}$ isobath, and the seismic survey area was divided into two areas (Johnson et al. 2007): Area A was that portion of the seismic block 4-5 km offshore from the $20 \mathrm{~m}$ isobath, and area B was that portion of the seismic block offshore from area A (Fig. 1). Seismic exploration activity only occurred in area A, closest to the whale feeding area, during daylight hours with good visibility, while area B was not subject to visibility restrictions.

Several monitoring programs were conducted before, during, and after the seismic survey to evaluate the effectiveness of the mitigation plan. These programs consisted of (1) acoustic monitoring, (2) vessel-based observations, (3) systematic aerial surveys of whales, and (4) shore-based observations of whale movements and behaviors. The acoustic monitoring (Borisov et al. 2002; Rutenko et al. 2007) was conducted to ensure sound levels did not exceed $163 \mathrm{~dB}$ re $1 \mu \mathrm{Pa}$ (rms) at the $20 \mathrm{~m}$ isobath, i.e., the 
outer edge of the whale feeding area while shooting in area B was being conducted. Vessel-based observations (Meier et al. 2002, 2007) were implemented to detect gray whales and initiate mitigation (airgun shutdown) when the vessel approached within 4$5 \mathrm{~km}$ of a gray whale (see Johnson 2002 and Johnson et al. 2007). Line-transect aerial studies (Yazvenko et al. 2002) were conducted pre-, during, and postexploration to determine distribution and abundance of gray whales, necessary to characterize distributional effects and to make near-real-time mitigation decisions (Johnson 2002; Johnson et al. 2007). In this study, we investigated the relative abundance, behavior, and movement patterns of western gray whales observable from shore in relation to temporal, environmental, and seismic related variables. The primary objective was to document western gray whale behavior and evaluate potential disturbance reactions by whales during the Odoptu seismic survey.

\section{Materials and methods}

Study area

Shore-based observations were conducted at five stations evenly spaced along $22 \mathrm{~km}$ of coast in the northeastern portion of Sakhalin Island (Fig. 1). The study area encompasses part of the Piltun feeding ground used by western gray whales, a food-rich habitat adjacent to Piltun Lagoon (Weller et al. 2002a; Fadeev 2002, 2003). Gray whales feed primarily on invertebrates in fine-grain benthic sediments. The Piltun feeding area is characterized by a sand substrate on a gradually sloping continental shelf (Fadeev 2002, 2003).

\section{Shore-based observation stations}

The five shore-based observation stations were situated immediately west of the Odoptu seismic survey area (Fig. 1). Each station was selected based on its height above sea level relative to the generally low-lying dunes of the area (station heights ranged from 8 to $16 \mathrm{~m}$ ), and distance (approx. $4-5 \mathrm{~km}$ ) to adjacent shore-based stations. Each station was occupied for a single day, which started in the South at Mount Kiwi and systematically moved northward to Muritai, and then returned to Mount Kiwi to repeat the cycle.

\section{Environmental measurements}

Environmental conditions were recorded several times/day. The relative visibility, glare concentration and horizontal angles, sea state (Beaufort scale), wind direction, cloud cover, and swell were recorded. Research effort was stopped when environmental conditions compromised observations, such as during sea states $\geq 4$ on the Beaufort scale, or during periods of poor visibility due to fog or rain. Other environmental variables (i.e., tide level, swell height, swell period) included in analyses were systematically recorded by either an ENL-operated oceanographic recording station located near station Midway, or on the Molikpak platform operated by Sakhalin Energy Investment Company (SEIC), located $37 \mathrm{~km}$ southeast from the study area.

\section{Scan sampling}

To monitor relative number of gray whales near the station in use on a given day, scan sampling was conducted hourly when focal behavior sessions (see below) were not being conducted. Two observers used hand-held $7 \times 50$ power reticle binoculars to scan a predetermined section of the study area ranging from 20 to $160^{\circ}$ magnetic North (8 to $148^{\circ}$ True North). Each scan started in the north and moved steadily to the south. The duration of each scan was $15 \mathrm{~min}$. When an observer made a whale sighting, the number of whales, angular distance between the whale(s) and the horizon (based on binocular reticles), magnetic bearing from the station to the whale(s), and estimated distance from the station to the whale(s) were recorded.

\section{Theodolite tracking}

Spatial and temporal movement patterns of gray whales were monitored with a Lietz/Sokkisha Model DT5A digital theodolite with 30-power monocular magnification and 5-s precision. This technique converts horizontal and vertical angles into geographic positions (latitude and longitude) upon each theodolite recording (see Würsig et al. 1991, 2002; 
Fig. 1 Geographic positions of five shore-based stations inshore of the "Odoptu Block" where marine seismic surveys were conducted in the northeastern coastal region of Sakhalin Island, Russia. Semi-circular grids illustrate approximate overlapping viewable range $(4 \mathrm{~km})$ from each shore-based station

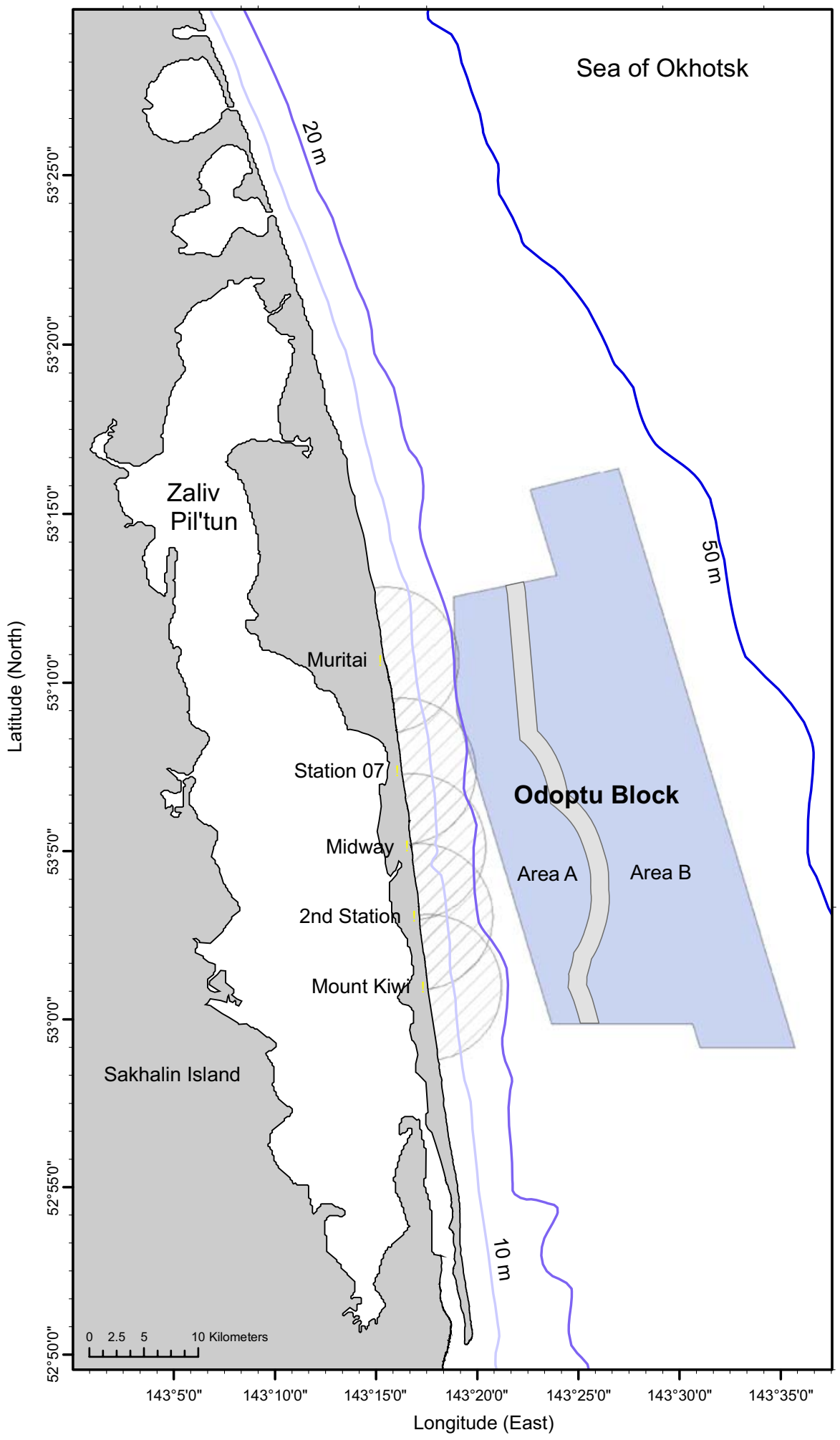


Gailey and Ortega-Ortiz 2002). A theodolite tracking session was initiated when a single or an individually recognizable gray whale was identified relatively close $(<4 \mathrm{~km})$ to the shore-based station. Each whale was tracked continually until the animal was no longer visible, moved beyond the $4 \mathrm{~km}$ distance, or environmental conditions prevented further tracking. For each theodolite recording (subsequently referred to as a fix), date, time, and vertical and horizontal angles were stored in a Microsoft Access ${ }^{\mathrm{TM}}$ database. Distance, bearing referenced to True North, and geographic position were calculated in real-time with the aid of the theodolite computer program Pythagoras $^{\mathrm{TM}}$ (Gailey and Ortega-Ortiz 2002), which incorporated tide height and curvature of the earth into the distance approximation. If a vessel moved to within $5 \mathrm{~km}$ of the whale being tracked, the theodolite operator tracked both objects to monitor speeds and orientations of the whale relative to movements of the vessel(s). Due to the relatively low elevations of the stations, theodolite tracking was limited to whales and vessels $\leq 4 \mathrm{~km}$ from the station to ensure reliable data for analysis (see Würsig et al. 1991 for height-related errors).

Focal-animal behavior observations

Focal-animal observations (Altmann 1974; Martin and Bateson 1993) were conducted on individual gray whales to determine if behavioral or respiration changes occurred in relation to environmental or seismic survey variables. A focal-animal behavior session was initiated when a single whale (focalanimal) could be monitored reliably enough so that respiration and critical behavioral events would not be missed. Not all single whales were individually identified from shore by eye, and it is possible that some focal follows were conducted on the same whale during a subsequent focal session. We believe this potential for pseudo-replication to be small within the same day, but larger for the same animals studied again on different days. A focal-animal session was terminated once the whale moved out of the study area or conditions did not meet minimum standards. At least one observer visually followed individuals with the aid of $7 \times 50$ hand-held binoculars. The behavioral observer verbally stated each behavioral event, and a computer operator recorded this information into the same laptop computer that was linked to the digital theodolite and ran the Pythagoras ${ }^{\mathrm{TM}}$ software
(Gailey and Ortega-Ortiz 2002). To minimize interobserver variability, the behavioral observer's observations were periodically evaluated by other observers. Most focal-animal sessions occurred in conjunction with theodolite tracking of the same focal-animal which provided the ability to link spatial details (i.e., geographic location, depth, etc) to behavioral observations.

\section{Acoustic monitoring}

Monitoring of ambient and seismic survey sounds near Odoptu in 2001 are described in detail in Borisov et al. (2002) and Rutenko et al. (2007). However, because seismic survey variables were important considerations when evaluating western gray whale movement and behavior characteristics, some details of the acoustic monitoring program are also presented here.

Sonobuoys used to measure received sound levels in the study area were deployed along the $20 \mathrm{~m}$ isobath, at the offshore edge of the Piltun feeding area (Borisov et al. 2002; Rutenko et al. 2007). Since sonobuoys were not deployed near feeding whales, various analytical techniques were employed to estimate received sound levels at locations where whales were observed. Received sound levels were determined for five specific locations along the $20 \mathrm{~m}$ isobath situated directly offshore from each of the five behavior observation stations; these locations were referred to as the "T1 points". Sound energy levels for each $\mathrm{T} 1$ point were estimated for specific time periods immediately prior to each behavior monitoring session (Borisov et al. 2002; Rutenko et al. 2007). Sound energy level estimation for T1 points involved the following steps: (1) computation of sound energy per shot at $1 \mathrm{~m}$ from the source, (2) computation of sound attenuation through the water column using a simple spreading model, specifically $25^{*} \log _{10}$ (distance), and (3) summation of the resulting estimates of received energy per shot at $\mathrm{T} 1$ locations over the time period of interest. While it is difficult to extrapolate sound intensities into shallow near-shore waters, this simple spreading model is acceptable here due to the proximity of the measuring hydrophones to the whales. Sound energy $1 \mathrm{~m}$ from source was estimated for 100 in. $^{3}$ (55\% of the shots), 370 in. $^{3}$ (2.5\%), 1,640 in. $^{3}(40 \%)$ and 3,090 in. $^{3}(2.5 \%)$ air-gun volumes (Borisov et al. 2002; Rutenko et al. 2007). Sound energy $1 \mathrm{~m}$ from source was estimated for the remaining air-gun volumes by interpolation. Received 
energy for each seismic shot was calculated by applying the spreading model to the distance between the sound source and T1 locations. Average energy received at $\mathrm{T} 1$ locations per shot for all shots in a given period was estimated by dividing the sum of the individual shot energies (from the previous steps) by the number of shots fired during the relevant period.

Received seismic survey sound energy (seg) was calculated for each T1 location during each 2-, 8-h, and 3-day period preceding each scan sampling session (seg2, seg8, seg3d). In addition, the number of air-gun shots during the 8 -h period prior to scan sampling was determined (shots $8 \mathrm{~h}$ ), and the number of shots with total air-gun volume $\geq 1,640$ in. $^{3}$ during the 2-h period prior to scan sampling was also determined (lshots2 h) (Rutenko et al. 2007).

Finally, since most gray whales recorded during each scan sampling, focal-animal follow, and theodolite tracking session were well within the $20 \mathrm{~m}$ isobath, it was necessary to represent received seismic sound energy estimates at a point more consistent with actual whale sighting/feeding locations. Thus, a location $2 \mathrm{~km}$ offshore from each of the five shorebased stations was determined, and separate range and depth functions (from $\mathrm{T} 1$ points to these locations) were derived to adjust received sound energy estimates for each of the five locations. Received sound energy estimates at $\mathrm{T} 1$ points and adjusted estimates for points $2 \mathrm{~km}$ offshore from behavior sampling stations comprised many of the seismic survey variables discussed below.

\section{Statistical analyses}

Univariate and multiple regression statistical analyses, including model development and testing, were conducted to evaluate relative abundance, temporal and spatial distribution and movements, and behaviors of western gray whales relative to environmental and seismic survey variables.

\section{Environmental and seismic survey variables}

Table 1 lists and describes all environmental and seismic survey variables included in the statistical analyses. Environmental variables consisted mainly of sea-state and weather-related measures. Most seismic survey variables were associated with estimated received sound energy levels at different locations relative to the seismic vessel and to western gray whales. Seismic survey variables were evaluated at three different temporal scales, over $2,8 \mathrm{~h}$, and 3 days, in order to evaluate potential short-term and long-term responses by the whales to seismic survey variables.

\section{Scan sampling}

The relative number of whales and number of pods were evaluated on a per-scan basis. All scan-sampling data were evaluated at two spatial levels: (1) on a broadscale for the entire study area with data from all stations pooled, and (2) on a station-by-station basis with comparisons within and between each of the five stations.

A multiple regression analysis relating whale and pod counts to environmental variables was fitted, and then seismic survey variables (estimated sound energy, number of shots, etc.) were introduced in subsequent steps to estimate the influences of these variables. A quasi-likelihood multiple regression model (McCullagh and Nelder 1989) was used because scan sampling data were not normally distributed. The quasi-likelihood regression model, assuming $n_{i}$ as the number of whales or pods sighted on scan $i$, was,

$\ln \left(E\left[n_{i}\right]\right)=\beta_{0}+\beta_{1} X_{1 i}+\ldots+\beta_{p} X_{p i}$

where $\beta_{j}$ was a coefficient to be determined in the analysis, and $X_{j i}$ was the value of the $j$-th explanatory variable during the $i$-th scan. The variance of $n_{i}$ was assumed to be

$\operatorname{var}\left(n_{i}\right)=\phi E\left[n_{i}\right]$,

where $\phi$ was an overdispersion parameter to be estimated.

Quasi-likelihood approximate $F$ tests (McCullagh and Nelder 1989; Venables and Ripley 1994; McDonald et al. 2000) were used to test for significant terms in the model. To construct a quasilikelihood regression model that explained natural variation of whale and pod counts, stepwise variable selection was used to include or exclude environmental variables (Table 1). The significance of each environmental variable in accounting for variability in scan count data was determined by the (type III) approximate $F$ tests $(\alpha=0.05)$.

Following analyses of environmental variables, seismic survey variables (Table 1) were introduced 
Table 1 Environmental and seismic exploration variables

\begin{tabular}{|c|c|c|}
\hline Type & Variable & Description \\
\hline \multirow[t]{17}{*}{ Environmental } & Station & Name of observation station where effort was conducted \\
\hline & Date & Julian date: number of days between January 1 to date of effort \\
\hline & Time & Hours from midnight \\
\hline & Beaufort & Sea state measured on the Beaufort scale \\
\hline & Visibility & Visibility estimated as 1 (good), 2 (moderate), 3 (poor) \\
\hline & Dist_Stn & Distance of whale observation from station platform \\
\hline & Tide_level & Tide level $(\mathrm{m})$ during observation \\
\hline & wind_direction & Categorical wind direction $(\mathrm{N}, \mathrm{E}, \mathrm{S}, \mathrm{W})$ \\
\hline & wind_speed & Speed of the wind $(\mathrm{m} / \mathrm{s})$ during observation \\
\hline & air_temp & Air temperature $\left({ }^{\circ} \mathrm{C}\right)$ during observation \\
\hline & wave_height & Wave height $(\mathrm{m})$ in vicinity of station \\
\hline & wave_period & Wave period (s) in vicinity of station \\
\hline & swell_height & Swell height $(m)$ in vicinity of station \\
\hline & swell_period & Swell period (s) in vicinity of station \\
\hline & Swell_direction & Categorical direction of swells in vicinity: $\mathrm{N}, \mathrm{E}, \mathrm{S}$ or $\mathrm{W}$ \\
\hline & storm3 & Hours between last storm with wave height $>3 \mathrm{~m}$ \\
\hline & storm4 & Hours between last storm with wave height $>4 \mathrm{~m}$ \\
\hline \multirow[t]{5}{*}{$\begin{array}{l}\text { Scan sampling seismic } \\
\text { variables }\end{array}$} & Shots8h & $\begin{array}{l}\text { Number of seismic exploration shots with gun volume }>0 \text { in. }{ }^{3} \text { in } 8 \text {-h period } \\
\text { immediately preceding the scan }\end{array}$ \\
\hline & Lshots $2 \mathrm{~h}$ & $\begin{array}{l}\text { Number of seismic exploration shots with gun volume } \geq 1,640 \text { in. }^{3} \text { in } 2 \text {-h period } \\
\text { immediately preceding the scan }\end{array}$ \\
\hline & Seg2 & $\begin{array}{l}\text { Total estimated received airgun sound energy at the ' } \mathrm{T} 1 \text { ' point during the } 2 \text {-h period } \\
\text { immediately preceding the scan (see text for definition of } \mathrm{T} 1 \text { ). }\end{array}$ \\
\hline & Seg8 & $\begin{array}{l}\text { Total estimated received airgun sound energy at the ' } \mathrm{T} 1 \text { ' point during the } 8 \text {-h period } \\
\text { immediately preceding the scan }\end{array}$ \\
\hline & $\operatorname{Seg} 3 \mathrm{~d}$ & $\begin{array}{l}\text { Total estimated received airgun sound energy at the ' } \mathrm{T} 1 \text { ' point during the } 3 \text {-day period } \\
\text { immediately preceding the scan }\end{array}$ \\
\hline \multirow[t]{6}{*}{$\begin{array}{l}\text { Theodolite and behavioral } \\
\text { seismic variables }\end{array}$} & Alongshore & $\begin{array}{l}\text { Straightline distance, parallel to mean coastline, from center of whale track observed } \\
\text { to point where seismic energy was estimated (seismic energy estimated at the 'T1' } \\
\text { point) }\end{array}$ \\
\hline & Seg & $\begin{array}{l}\text { Estimated total amount of airgun sound energy received at the 'T1' point based on gun } \\
\text { volume and a simple propagation model (see text) }\end{array}$ \\
\hline & Seismic & $\begin{array}{l}\text { Categorical classification of airgun sound received at the ' } \mathrm{T} 1 \text { ' point based on gun } \\
\text { volume: } \mathrm{N}=\text { no sound=guns not firing, } \mathrm{W}=\text { weak total gun volume }<320 \mathrm{in}^{3}, \mathrm{~S}= \\
\text { strong total gun volume } \geq 320 \mathrm{in}^{3}, \mathrm{P}=\text { post-seismic }=\text { no sound because seismic } \\
\text { exploration program had ceased }\end{array}$ \\
\hline & Shoreward & $\begin{array}{l}\text { Straightline distance, perpendicular to mean coastline, from center of whale track } \\
\text { observed to point where seismic energy was estimated (seismic energy estimated at } \\
\text { the ' } \mathrm{T} 1 \text { ' point) }\end{array}$ \\
\hline & Shots & Total number of airgun shots of any volume \\
\hline & since_370 & $\begin{array}{l}\text { Number of hours between the last shot with airgun volume exceeding } 370 \mathrm{in}^{3} \\
\text { and the start of the tracking bin }\end{array}$ \\
\hline
\end{tabular}

one-at-a-time (stepwise) to the model. The significance of each seismic survey variable was assessed using $F$ tests. Acceptance of any of the seismic survey variables into the model indicated that the variable explained a significant portion of the variation in whale counts that could not be explained by the environmental variables.
Moran's I test (Moran 1950) was used to evaluate regression residuals to determine whether autocorrelation in whale counts adversely affected significance levels of terms in the final quasi-likelihood model. Generalized mixed linear model estimation procedures were used to adjust for significant autocorrelation. 


\section{Focal-animal follows}

Focal-animal (whale) follows were conducted simultaneously with theodolite tracking of western gray whales. Focal-whale behavior data were quantified as six variables: (1) blow interval (times less than $60 \mathrm{~s}$ between subsequent exhalations per surfacing), (2) number of blows per surfacing, (3) surface time (duration the animal remains at or near the surface), (4) dive time (logged whenever a submerged whale did not blow for $>60 \mathrm{~s}$ ), (5) surface blow rate (mean number of exhalations per minute during a surfacing), and (6) surface-dive blow rate (number of exhalations per minute averaged over the duration of a surfacingdive cycle). Each of these behavior variables was evaluated relative to (1) environmental variables and (2) seismic survey variables, when simultaneous theodolite tracking and focal behavior sessions occurred.

All focal-whale follows (and theodolite tracks) were "binned" into 10-min intervals to standardize the units of measurement during statistical analysis. "Binning" involved combining locations within discrete intervals approximately $10 \mathrm{~min}$ long, and viewing these intervals as the basic units of observation. Each "bin" ended at an actual whale location, so bins varied in length, and one or more bins occurred within each track. The above-mentioned six behavioral variables, along with seismic survey variables measured during each 10-min period, were calculated and used in the statistical analyses. Lack of independence and resultant pseudoreplication among consecutive "bins" were investigated and where necessary, adjustments were made (some data were not considered) during the multiple regression analysis (see discussion below). For univariate analyses, one randomly selected bin per trackline/focal-animal follow was used to avoid potential concern of lack of independence.

\section{Theodolite tracking}

Theodolite tracking data were evaluated in terms of each whale's relative speed, direction, and orientation. Due to the potential for oversampling or undersampling and to ensure that fixes within a single whale theodolite track were independent (uncorrelated), each trackline was resampled temporally, as suggested by Turchin (1998), and an autocorrelation analysis was conducted. An autocorrelation coeffi- cient near zero occurred at around the second-third whale position (data point) fix along a trackline, which averaged about $90 \mathrm{~s}$ after the first fix. Thus, a $90 \mathrm{~s}$ resampling regime was adopted for all theodolite tracking data.

Calculated leg speed, linearity, reorientation rate, mean vector length, acceleration, and distance-fromshore were analyzed for each resampled trackline. Leg speed was estimated by calculating the distance traveled between two sequential fixed points within a trackline, and dividing this difference by the time interval between the two fix points. Linearity was an index of deviation from a straight line, calculated by dividing the net geographic distance between the first and last fix of a trackline by the cumulative distances along the track. Linearity values range between 0 and 1 , with 0 indicating no net movement and 1 indicating a straight line (Batschelet 1980). A directionality index $r$ (mean vector length; Cain 1989) was incorporated due to its dependence on angular change within a trackline. Mean vector length values range from 0 (great scatter) to 1 (all movements in the same direction; Cain 1989). Reorientation rate represents a magnitude of bearing change along a trackline. This rate was calculated as the sum of the absolute values of all bearing changes from one leg to the next along a trackline, divided by the entire duration of the trackline (Smultea and Würsig 1995).

The entire analysis data set included the 11 movement and behavioral variables, and all environmental, temporal, and seismic survey variables (Table 1) from 815 bins of theodolite tracking and focal-animal follows. Correlation analyses were conducted to detect collinearity among variables and avoid instability and loss of precision in estimates (Ramsey and Schafer 1997). If collinearity was found within the dataset, as indicated by a correlation coefficient $>0.70$, the confounding variable(s) was (were) excluded from the analysis.

The regression models required that the distribution of model variables be approximately normal, and that behavior/movement variables be independent of one another (Neter et al. 1985). Thus, prior to model building, the distribution of every behavior/movement variable was investigated and, where necessary, transformed to make the transformed variable approximately normal. Analysis of residuals was determined by visually inspecting histograms. Six of the 11 behavior/movement variables had non-normal distri- 
butions and were transformed. Empirical logit transformation was applied to linearity and mean vector length because their distributions were highly skewed, non-normal in shape, and contained values that ranged from 0 to 1 . The distributions of leg speed, reorientation rate, blows/surfacing, and surface time were also non-normal and were log-transformed.

Stepwise variable selection was used to include or exclude significant environmental and temporal variables. This stepwise procedure was identical to that used in the analysis of scan count data described above. All variables except date and hour were considered linear or main effects; date and hour effects were linear and quadratic (curvilinear).

If no environmental, temporal, or seismic survey variables entered the model at $\alpha=0.05$, the model building process was repeated using $\alpha=0.10$. A Moran's $I$ test (Moran 1950) was used to ensure that temporal autocorrelation did not adversely affect significance levels of terms in the final regression models. If temporal correlation was found in the residuals (Moran's $I>0.5$ ), weighted least squares (with estimated covariance matrix) or generalized mixed linear models were used to adjust for the correlation.

\section{Results}

Effort

A total of 36 days (261 h) of effort were spent at the five shore-based stations adjacent to the Odoptu Block during 1 August to 22 September 2001. Of this total, 24 days $(189 \mathrm{~h})$ were during periods of intermittent seismic survey activity, and 12 days $(72 \mathrm{~h})$ were after the seismic survey had ended. Sampling effort was approximately equal from the five shore-based stations: 9 days $(60.08 \mathrm{~h})$ at Mt. Kiwi, 7 days $(41.32 \mathrm{~h})$ at 2 nd Station, 6 days $(57.27 \mathrm{~h})$ at Midway, 8 days $(52.58 \mathrm{~h})$ at Station 07, and 6 days $(49.75 \mathrm{~h})$ at Muritai.

Scan sampling

\section{Univariate statistical analyses}

No statistically significant differences in the numbers of whales or pods recorded during scan sampling were detected during periods of seismic surveys vs. after the seismic surveys (Table 2). A total of 191 scans were conducted over the 36 days of sampling. Mean number of scans per day was $5.5( \pm$ SD 2.59). Gray whales were present on each day of sampling with a mean of $2.6( \pm$ SD 2.07 , median $=2$, range: 0 $10, N=191)$ whales and $1.9( \pm 1.63,1.5,0-6,191)$ pods per scan (Fig. 2). The overall mean pod size for the entire study period was $1.4( \pm 0.71,1,1-6,355$; Fig. 2). The numbers of whales and pods observed at each station were different. Average number of whales and pods at the southern-most station (Mt. Kiwi, $\bar{\chi}=4.0 \pm 2.70$ whales and $2.6 \pm 1.43$ pods) were higher than at the other four stations. The numbers of whales and pods at the other four stations were similar (range: $1.8 \pm 1.35$ to $2.7 \pm 1.87$ whales and $1.3 \pm 0.94$ to $2.0 \pm 1.25$ pods) with fewest whales and pods seen from Station 07. During the period of seismic activity the average numbers of whales $(\bar{\chi}=2.8 \pm 2.16)$, pods $(2.0 \pm 1.32)$, and pod size $(1.4 \pm 0.74)$ were similar to those during the post-seismic period (whales $=2.3 \pm$ 1.79 , pods $=1.6 \pm 1.15$, and pod size $=1.4 \pm 0.60$ ).

\section{Multivariate statistical analyses}

As with the univariate statistical analyses, multivariate statistical analyses of scan sampling data indicated no significant differences in numbers of western gray whales or pods of whales during vs after the seismic surveys. The final multiple regression model for the numbers of whales and pods seen during a scan included station, tide level, and visibility variables, but no seismic survey variables. The final whale count model was

Table 2 Number of pods $(F=1.7787, d f=3, P=0.1531)$ and whales $(F=1.149, d f=3, P=0.3308)$ per scan sample during different seismic events

\begin{tabular}{llllll}
\hline Category & Mean & SD & Median & Range & $N$ \\
\hline Pods & & & & & \\
None & 2.2 & 1.55 & 2 & $0-6$ & 34 \\
Strong & 2.0 & 1.27 & 2 & $0-5$ & 78 \\
Weak & 1.5 & 0.98 & 1 & $0-3$ & 24 \\
Post & 1.6 & 1.15 & 1 & $0-5$ & 55 \\
Whales & & & & & \\
None & 3.3 & 2.89 & 2 & $0-10$ & 34 \\
Strong & 2.8 & 1.91 & 2 & $0-8$ & 78 \\
Weak & 2.1 & 1.53 & 2 & $0-5$ & 24 \\
Post & 2.3 & 1.79 & 2 & $0-7$ & 55 \\
\hline
\end{tabular}




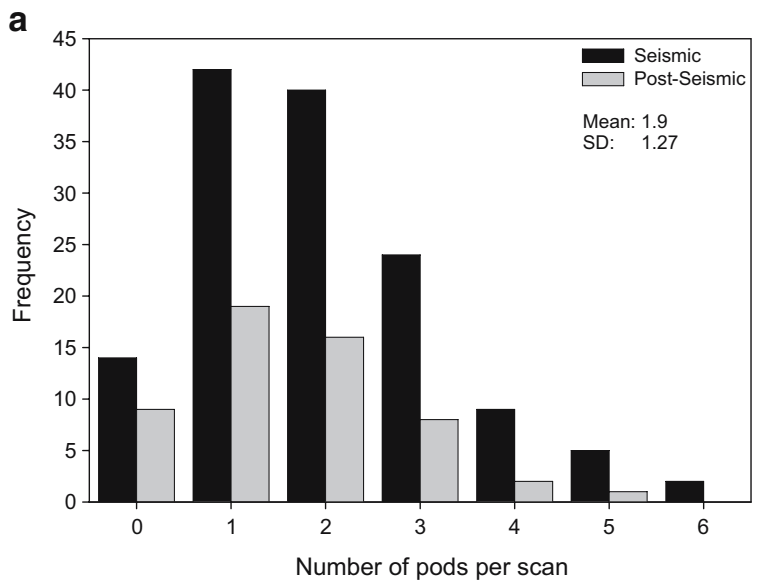

b

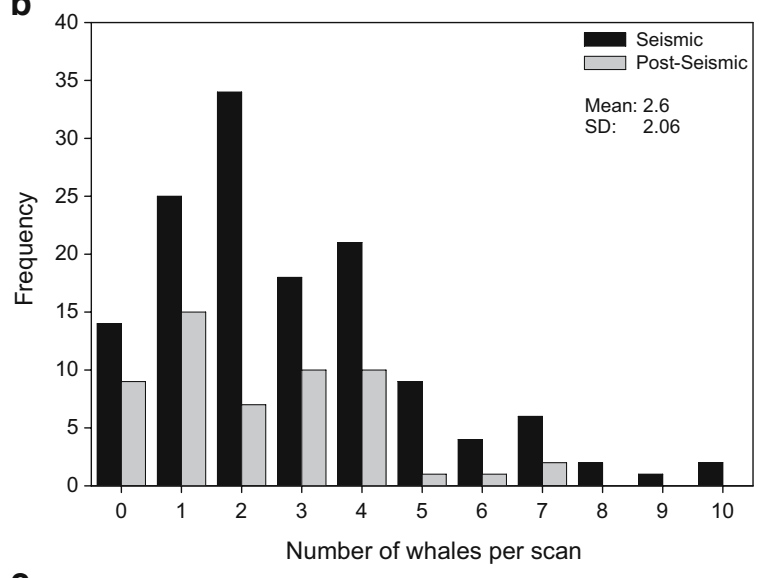

C

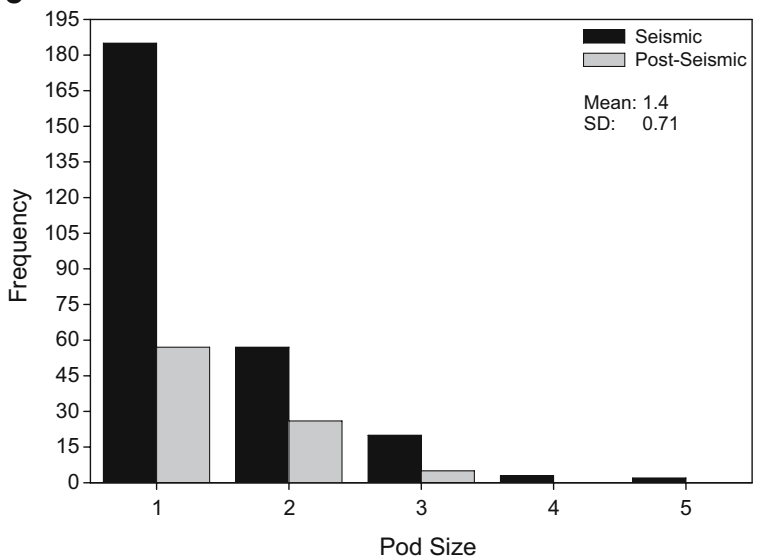

Fig. 2 Overall frequency distributions of number of pods (a), number of whales (b), and pod size (c) per scan

$\log (E[$ whale count $])=0.7886+0.4341$ (Midway) $+0.7575($ Mt. Kiwi $)$ +0.2560 (Muritai) +0.2152 (Second Station) -0.3879 (tide_level) +0.2213 (Visibility 1$)$ +0.4967 (Visibility 2), $\log (E[$ pod count $])=0.7342+0.4395$ (Midway) +05902 (Mt.Kiwi)

$$
\begin{aligned}
& +0.1149 \text { (Muritai) }+0.2574(\text { Second Station }) \\
& -0.5368(\text { tide_level })+0.1478(\text { Visibility } 1) \\
& +0.4613 \text { (Visibility } 2)
\end{aligned}
$$

where Midway, Mt.Kiwi, Muritai and Second Station were indicator functions (e.g., Midway=1 for scans conducted at Midway, Midway $=0$ for all other scans; other station variables defined similarly) for the different observation stations (with Station 07 being the "standard"), and tide_level and visibility were indicators of sightability at the different stations.

Coefficients for the stations indicated that the average numbers of whales and pods seen per scan by an observer at Midway were 1.54 and 1.55 times those at Station $07\left(e^{0.4341}=1.54\right)$. The average values from Mt. Kiwi were estimated to be 2.13 (whales) and 1.80 (pods) times those at Station 07. Average scan count from Muritai and Second Station were 1.29 whales/1.12 pods and 1.24 whales/ 1.29 pods, respectively, times higher than the average count at Station 07.

Tide range was as much as $1.25 \mathrm{~m}$ between low and high tide, but averaged around $0.75 \mathrm{~m}$. For a $1-\mathrm{m}$ rise in the tide level, there was an estimated $32 \%$ decrease in the average number of whales and $42 \%$ decrease in the average number of pods seen during a scan. During scans with good and moderate visibility (Visibility=1 and 2), average counts were 1.25 and 1.64 times higher for number of whales and 1.16 and 1.59 times for number of pods, respectively, than average counts during times of poor visibility (Visibility $=3$ ).

Positive but small temporal correlation was found in the deviance residuals from the final models for both the number of whales (Moran's $I=0.31,95 \% \mathrm{CI}$ : 0.13 to 0.50 ) or number of pods (Moran's $I=0.34$, 95\% CI: 0.02 to 0.66 ). This level of temporal correlation was unlikely to substantially affect environmental variable coefficient estimates. Furthermore, accounting for this small temporal correlation through use of a generalized mixed linear model would only have increased the $p$ values associated with all seismic survey variables. Because our main conclusions regarding the association between seismic survey variables and whale or pod counts would not have changed (see below), we report the unadjusted (for temporal correlation) quasi-likelihood model with effective sample sizes slightly higher than if they had been adjusted.

None of the five seismic survey variables (Table 1) explained a significant amount $(p<0.05)$ of residual 
Table $3 P$ values for seismic effect variables considered for the final model for the number of whales and pods seen during a scan

\begin{tabular}{|c|c|c|c|c|c|c|}
\hline \multirow[t]{2}{*}{ Model } & \multirow[t]{2}{*}{ Seismic parameter } & \multirow[t]{2}{*}{$d f$} & \multicolumn{2}{|l|}{ Number of whales } & \multicolumn{2}{|l|}{ Number of pods } \\
\hline & & & Approximate $F$ statistics & $P$ & Approximate $F$ statistics & $P$ \\
\hline 1 & Seg2 & 1 & 0.28 & 0.599 & 0.11 & 0.746 \\
\hline 2 & Seg8 & 1 & 0.00 & 0.948 & 0.00 & 0.987 \\
\hline 3 & Shots8h & 1 & 0.63 & 0.430 & 0.02 & 0.645 \\
\hline 4 & Lshots $2 h$ & 1 & 0.06 & 0.809 & 0.60 & 0.438 \\
\hline 5 & $\operatorname{Seg} 3 d$ & 1 & 1.40 & 0.238 & 0.06 & 0.424 \\
\hline
\end{tabular}

variation in whale or pod counts. Levels of statistical significance for the five seismic survey variables varied from 0.24 to 0.95 for numbers of whales and 0.42 to 0.99 for numbers of pods, after allowance for environmental variables (Table 3).

Theodolite tracking and focal-animal behavior

Gray whales were tracked by theodolite for $127 \mathrm{~h}(\bar{\chi}=$ $59.0 \mathrm{~min} /$ track), ranging from $10 \mathrm{~min}$ to $6 \mathrm{~h}$ of continuous monitoring of movements. There were 130 different tracklines with 7,412 geographic positions with $95 \mathrm{~h}$ (95 tracklines, 5,356 positions) during periods of intermittent seismic surveys (01 August to 08 September) and $32 \mathrm{~h}$ (35 tracklines, 2,056 positions) of trackline information post-seismic (0922 September) activity. Focal-follow behavioral observations were conducted for a total of $47.5 \mathrm{~h}$ on 52 individual gray whales from 01 August to 22
September 2001. The mean duration of a focal-follow session was approximately $55 \mathrm{~min}$.

\section{Univariate statistical analyses}

Univariate statistical analyses of theodolite and behavior variables indicated no significant statistical relationships for any of the 11 behavior/movement variables relative to seismic survey variables (Table 4).

\section{Multivariate statistical analyses}

The quasi-likelihood step-wise regression analyses indicated that most of the behavior/movement variables were significantly correlated with some environmental variables. The analyses also showed that 6 of 11 behavior/movement variables were not correlated with seismic survey variables, and 5 of 11 behavior/movement

Table $4 P$ values for univariate (ANOVA) analysis of trackline and behavioral variables in relation to "Seismic" (classified as "none", "weak", "strong", and "post") and "Seismic with Distance" (classified as "none", "weak" $\leq 10 \mathrm{~km}$, "weak" $>10$ km, "strong" $\leq 10 \mathrm{~km}$, "strong" $>10 \mathrm{~km}$, and "post")

\begin{tabular}{|c|c|c|c|c|c|c|c|}
\hline \multirow[t]{2}{*}{ Variable } & & \multicolumn{3}{|l|}{ Seismic } & \multicolumn{3}{|c|}{ Seismic with distance } \\
\hline & & $F$ statistic & $d f$ & $P$ & $F$ statistic & $d f$ & $P$ \\
\hline \multirow[t]{5}{*}{ Trackline } & Leg speed & 1.62 & 3 & 0.188 & 1.23 & 5 & 0.297 \\
\hline & Linearity & 1.18 & 3 & 0.321 & 1.15 & 5 & 0.338 \\
\hline & Acceleration & 1.05 & 3 & 0.374 & 0.15 & 5 & 0.981 \\
\hline & Reorientation rate & 0.75 & 3 & 0.525 & 1.33 & 5 & 0.256 \\
\hline & Track R & 0.28 & 3 & 0.839 & 0.64 & 5 & 0.671 \\
\hline \multirow[t]{6}{*}{ Behavioral } & Blow interval & 0.78 & 3 & 0.511 & 0.80 & 5 & 0.557 \\
\hline & Blows per surfacing & 1.73 & 3 & 0.171 & 0.21 & 5 & 0.959 \\
\hline & Surface time & 0.30 & 3 & 0.823 & 0.53 & 5 & 0.755 \\
\hline & Dive time & 0.26 & 3 & 0.852 & 1.66 & 5 & 0.158 \\
\hline & Surface blow rate & 2.33 & 3 & 0.085 & 2.28 & 5 & 0.058 \\
\hline & Surface-dive blow rate & 0.11 & 3 & 0.955 & 1.46 & 5 & 0.685 \\
\hline
\end{tabular}


Table 5 Summary of 11 quasi-regression models relating behavioral responses to environmental and industrial variables

\begin{tabular}{|c|c|c|c|c|c|c|c|c|c|c|c|c|}
\hline \multirow[t]{2}{*}{ Variable type } & \multirow[t]{2}{*}{ Explanatory variable } & \multicolumn{11}{|c|}{ Response Variable } \\
\hline & & $\operatorname{lin}$ & legspd & deltalgsp & $\mathrm{rr}$ & trackr & dist_shore & bi & b_p_s & s_time & d_time & s_d_rate \\
\hline \multirow[t]{29}{*}{ Environmental } & Air_temp & & n.s. & & ++ & & & & & & & \\
\hline & $\begin{array}{l}\text { Beaufort (reference } \\
\text { level=4) }\end{array}$ & & & & & & & & & & & \\
\hline & Beaufort $=1$ & & n.s. & & n.s. & & + & & & & +++ & \\
\hline & Beaufort $=2$ & & -- & & $(+)$ & & n.s. & & & & +++ & \\
\hline & Beaufort $=3$ & & $(-)$ & & n.s. & & n.s. & & & & +++ & \\
\hline & Date & $(-)$ & n.s. & & & - & & & & & -- & n.s. \\
\hline & Date $^{2}$ & + & & & & & & & & & ++ & n.s. \\
\hline & Dist_station & --- & +++ & & +++ & & & & & & & \\
\hline & Hour & & n.s. & & & n.s. & & --- & -- & - & & --- \\
\hline & Hour $^{2}$ & & n.s. & & & n.s. & & & + & n.s. & & +++ \\
\hline & $\begin{array}{l}\text { Station (reference } \\
\text { level=Midway) }\end{array}$ & & & & & & & & & & & \\
\hline & Muritai & +++ & n.s. & & -- & n.s. & ++ & +++ & & & + & n.s. \\
\hline & Mt.Kiwi & +++ & n.s. & & --- & ++ & n.s. & + & & & +++ & n.s. \\
\hline & Station 07 & n.s. & ++ & & n.s. & n.s. & ++ & +++ & & & n.s. & n.s. \\
\hline & Second Station & n.s. & +++ & & n.s. & -- & n.s. & +++ & & & -- & +++ \\
\hline & Storm3 & + & ++ & $(-)$ & & & n.s. & & - & & - & \\
\hline & $\begin{array}{l}\text { Swell_dir (reference } \\
\text { level=N) }\end{array}$ & & & & & & & & & & & \\
\hline & Swell_dir=E & & n.s. & & & & & --- & & & n.s. & \\
\hline & Swell_dir $=S$ & & +++ & & & & & + & & & --- & \\
\hline & Swell_dir $=\mathrm{W}$ & & n.s. & & & & & n.s. & & & -- & \\
\hline & Tide & & & & --- & ++ & n.s. & -- & & & +++ & --- \\
\hline & $\begin{array}{l}\text { Visibility (reference } \\
\text { level=3) }\end{array}$ & & & & & & & & & & & \\
\hline & Visibility $=1$ & +++ & +++ & & --- & & +++ & ++ & & & & \\
\hline & Visibility $=2$ & n.s. & n.s. & & n.s. & & n.s. & $(-)$ & & & & \\
\hline & Wave_hgt & & ++ & & & & --- & & & & & + \\
\hline & $\begin{array}{l}\text { Wind_dir (reference } \\
\text { level=N) }\end{array}$ & & & & & & & & & & & \\
\hline & Wind_dir $=\mathrm{E}$ & & - & & & ++ & & & n.s. & n.s. & n.s. & \\
\hline & Wind_dir $=\mathrm{S}$ & & --- & & & n.s. & & & + & + & ++ & \\
\hline & Wind_dir $=\mathrm{W}$ & & -- & & & +++ & & & + & n.s. & n.s. & \\
\hline \multirow[t]{9}{*}{ Seismic } & Alongshore & & & & & & & & & & & \\
\hline & Seg & & ++ & & - & & +++ & +++ & & & & \\
\hline & Seismic $($ reference $=N)$ & & & & & & & & & & & \\
\hline & Seismic $=\mathrm{S}$ & & n.s. & & & & +++ & & & & n.s. & \\
\hline & Seismic $=\mathrm{P}$ & & +++ & & & & + & & & & --- & \\
\hline & Seismic $=\mathrm{W}$ & & ++ & & & & ++ & & & & n.s. & \\
\hline & Shoreward & & & & & & & +++ & & & & \\
\hline & Shots & & & & & & & & & & & \\
\hline & Since_370 & & & & & & & ++ & & & & \\
\hline Sample Size & & 482 & 510 & 506 & 506 & 482 & 510 & 271 & 234 & 241 & 239 & 236 \\
\hline Max Moran's I ${ }^{\mathrm{a}}$ & & 0.11 & 0.14 & 0.05 & 0.11 & 0.09 & 0.47 & 0.2 & 0.12 & 0.15 & 0.24 & 0.18 \\
\hline
\end{tabular}

One or more ' + ' in a cell indicates a positive estimated coefficient. One or more '- ' indicates a negative estimated coefficient. ' +++ ' in a cell indicates $0<p \leq 0.001$, ' ++ ' indicates $0.001<p \leq 0.01$, ' + ' indicates $0.01<p \leq 0.05$, ' $(+)$ ' indicates $0.05<p \leq 0.1$, 'n.s.' for $p>0.1$, and blank cells are variables not included in the final model

${ }^{\text {a }}$ Upper limit of $95 \%$ confidence interval on correlation of residuals within $30 \mathrm{~min}$ of one another 
variables were significantly correlated with seismic survey variables. No temporal correlations were found in the residuals from any of the final models, thus no autocorrelation adjustments to the data were necessary.

\section{Correlations with environmental variables}

Linearity was correlated with date, distance-fromstation, two of the observation stations, recent storm, and visibility (Table 5). Leg speed (legspd) was correlated with sea state (Beaufort scale), distance-fromstation, two of the observer stations, recent storm, swell direction, visibility, wave height, and wind direction. Acceleration was not significantly correlated with any environmental variables. Reorientation rate (rr) was correlated with air temperature, sea state, distance-from-station, two of the observation stations, tide height, and visibility. Mean direction of the whale (trackr) changed with date, two of the observation stations, tide, and wind direction. Distance-from-shore (dist_shore) was related to sea state, two of the observation stations, visibility, and wave height.

Surfacing-respiration-dive parameters also showed significant correlations with environmental and temporal variables. Blow interval (bi) was affected by hour of day, observation stations, swell direction, tide height, and visibility. Mean number of exhalations per minute while whales were at the surface (b_p_s) was correlated with hour of day, recent storm, and wind direction. Surface time (s_time) was significantly correlated with hour of day and wind direction. Dive time (d_time) was correlated with most environmental variables, including sea state, date, observation station, swell direction, recent storm, tide, and wind direction. Finally, the surfacing-dive rate (s_d_rate) varied with hour of the day, observer station, tide height, and wave height.

Correlations with seismic survey variables There was no statistical evidence that changes in gray whale directionality indices (linearity [lin] and mean direction [trackr]), changes in speed between fixes (acceleration), mean number of exhalations per minute at the surface (b_p_s), mean time at the surface (s_time), and mean number of exhalations per minute during a surface-to-dive cycle (s_d_time) were correlated with seismic survey variables. Environmental and temporal variables sufficiently explained the majority of variation in these behavior/movement and temporal variables (Table 5). In contrast, 5 of 11 behavioral/movement variables were significantly correlated with estimates of airgun sound energy (seg) and some other seismic survey variables (Table 5).

-Leg speed was correlated with estimated received sound energy (seg) and classification of the sound energy (seismic). Leg speed increased when sound energy from the seismic survey increased. However, leg speed also tended to be higher during 'weak' and 'post-seismic' periods compared to "no seismic" periods. The categorization of 'strong' seismic periods, however, was not found to be significantly associated with leg speed.

-Reorientation rate was lower during periods of increased sound from seismic exploration.

-Distance (of whale)-from-shore was greater during periods of estimated high received seismic sound energy (seg), and during periods classified as 'weak' and 'strong' when compared to periods classified as 'none'. However, distance-fromshore also appeared to be higher during 'postseismic' periods.

-Blow interval tended to increase as seismic sound (seg) increased, as the amount of time since the last shot with volume greater than 370 in. $^{3}$ (since_370) increased, and as distance to the seismic energy source (shoreward) increased. -Dive time tended to be less during the "postseismic' period than during the "no seismic" period, but was not significantly different during the 'none', 'weak', and 'strong' periods of estimated received seismic sound energy.

Taken together, these results of the multiple regression analysis indicated that gray whales increased their speed, changed directions less, moved further from shore, and stayed under water longer between respirations when estimated received sound energy from the seismic survey increased.

\section{Discussion}

This study used univariate and multivariate statistical analytical procedures to evaluate the relative abundance, behavior, and movement patterns of western gray whales in relation to environmental and temporal variables and anthropogenic seismic activity. Gray 
whales were present during each day of effort, with and without seismic surveys just offshore, indicating strong site fidelity to this near-shore area. Such fidelity for feeding gray whales has also been described for the eastern population (i.e., Pike 1962; Hatler and Darling 1974; Darling 1984; Würsig et al. 1986; Dunham and Duffus 2002), as well as the western population (Weller et al. 1999).

Mean pod size was small - 1.4 whales per pod, with a range of one to six whales. This is consistent for bottom or near-bottom feeding gray whales, and is slightly less than the mean and median of two whales per pod reported for this population by Weller et al. (1999). Weller et al. (1999) gathered data 15-25 km south of the present study area, where whales tended to aggregate near the mouth of Piltun Lagoon. Considerably more whales occurred at the southernmost station, Mt. Kiwi, than at the four more northerly stations. However, the relative numbers of whales and pods at each behavior sampling station in the study area were not significantly different during the seismic survey activity. Daily behavior sampling, however, occurred over a single relatively small area compared to aerial and shipboard surveys. The aerial survey program conducted during the seismic survey period indicated a southward shift by five to ten gray whales during the seismic survey period (Yazvenko et al. 2002, 2007a,b), which may, in part, account for the larger number of whales observed at the southernmost shore-based station. Likewise, Weller et al. (2002b) recorded larger numbers of whales during the seismic survey period, compared to the pre- and post-seismic survey periods, at their Piltun lighthouse observation station located $25 \mathrm{~km}$ south of the Odoptu study area, also indicating potential displacement of at least some gray whales to the southern part of the feeding area. Similar types of movements by large baleen whales have been recorded during seismic surveys. Richardson et al. (1999) reported that sighting rates of bowhead whales during aerial surveys in the Beaufort Sea were lower when the whales were exposed to seismic survey sounds of $120-130 \mathrm{~dB}$ re $1 \mu \mathrm{Pa}$ (rms), indicating a movement response at sound levels lower than had previously been reported for bowhead whales (Richardson et al. 1986; Richardson and Würsig 1997).

Univariate statistical analyses similar to those used in previous studies indicated no statistical relationship between seismic survey variables and the behavior and movement patterns of western gray whales.
A behavioral study of western gray whales conducted south of the Odoptu Block in July-October 1997 (Würsig et al. 1999) gathered similar behavioral data. In this earlier study, a seismic ship was using an air-gun array to conduct a seismic survey in the vicinity of the Piltun lighthouse. Precise information was not available, however, regarding the exact position of the seismic vessel, and when the air-guns were firing. Univariate statistical analyses of data from 1997 indicated that leg speed increased and reorientation rate decreased during the general period of the seismic survey. Dive time showed a slight statistically non-significant decrease during the seismic survey. Interestingly, blow interval marginally decreased during the seismic survey, which was opposite to our findings in this 2001 study, and to findings in studies of eastern gray whales and bowhead whales in Alaskan waters (Malme et al. 1987; Ljungblad et al. 1988). There is no clear explanation why blow interval decreased, rather than increased, during the seismic survey period in the 1997 studies. However, one important difference between the 1997 and 2001 studies was the inclusion of environmental and temporal variables in statistical analyses conducted in 2001. In 2001, all behavioral variables were significantly correlated with some of these "natural" variables that were not considered during 1997.

In contrast with the univariate analyses used in previous studies, multiple regression analyses of 2001 data indicated that five of the eleven behavioral and movement variables were statistically associated with seismic survey variables, after allowance for environmental and temporal variables. Leg speed increased significantly with increasing estimated received sound energy, low seismic gun volume, and post-seismic survey period. Reorientation rate was significantly lower during periods of increased estimated received seismic sound energy. One interpretation of these results regarding leg speed and reorientation rate is that whales fed less and traveled more during periods of estimated higher exposure to received seismic survey sound energy. Increased whale swimming speed during the post-seismic period, i.e., during approximately the last two weeks of September, could potentially have been caused by the onset of migration to wintering/breeding grounds, or by a change in prey distribution or feeding strategy. Distance of whale-from-shore increased with increasing estimated received sound energy as well as with low and high 
air-gun volumes. Blow interval increased with increasing estimated received sound energy, distance from whale to the seismic energy source, and time since last seismic firing with air-gun volume above 370 in. $^{3}$ Finally, dive time decreased during the postseismic survey period but was not significantly correlated with estimated received sound energy or 'weak'/'strong' seismic categorizations. The increase in blow interval and decrease in dive time were also documented during a seismic air-gun experiment near eastern gray whales in the northern Bering Sea (Malme et al. 1987) and near an actively shooting seismic vessel in close proximity to bowhead whales in the western Beaufort Sea (Ljungblad et al. 1988).

In summary, this study demonstrated that most measures of western gray whale behavior and movement patterns were correlated with environmental and temporal variables, i.e., natural variables. In addition, significant correlations were documented between five measures of western gray whale movement and behavior patterns and various measures of potential impact from the marine 3-D seismic survey. In contrast, six movement and behavior variables were not significantly correlated with marine seismic survey variables with the use of the multiple regression approach. There was a great deal of "natural" variability among all measures of western gray whale behavior and movement on the feeding grounds during 2001, and it is imperative that this variability be considered at all times and under all circumstances of study of western gray whales. Potentially important information that was not considered in this study, such as western gray whale prey availability (distribution and abundance of food), may aid in accounting for observed variations in whale movement and behavior models.

Despite the potential effects on behavior and movements, whales remained in the general area and continued to feed during the period of the 2001 seismic survey program; however, it is uncertain whether long-term exposure and/or an increase in anthropogenic activity off northeast Sakhalin Island will result in sensitization and displacement of whales, or, to the contrary, habituation and progressive reduction in observable impacts on western gray whale behavior. Clearly this study area is critically important feeding habitat needed to energetically sustain western gray whales during their migration and breeding periods. The possibility of displacement is of primary concern, due to the expected increasing level of anthropogenic activity and the possibility of cumulative impacts as industrial development continues. Therefore, it is important to monitor and identify potential problems and suggest alternatives to practices that may be impacting this endangered population.

Acknowledgements $\mathrm{We}$ are grateful to Boris Antonov, Dorothy Baker, Nichollette Brown, Bob Brownell, Mike Jenkerson, Steve Johnson, Roman Korottihenko, Caroline Martin, Rodger Melton, Victor Protivich, Alexander Rutenko, Olga Sychenko, Karina Tarasyan, David Weller, and Sergei Yazvenko for providing logistical support in the field. We also thank Rolph Davis, Mike Jenkerson, Steve Johnson, Chuck Malme, Caroline Martin, Rodger Melton, Keith Parker, and W. John Richardson for providing advice and assistance on all levels of this project. Nichollete Brown, Ryan Nielson, Joel G. Ortega-Ortiz, and Peter Wainwright provided database and statistical assistance. We also appreciate the support and camaraderie from the staff of LGL Limited, ExxonMobil, and the Marine Mammal Research Program at Texas A\&M University at Galveston. This project was funded by Exxon Neftegas Limited, and the preparation of the paper was jointly funded by Exxon Neftegas Limited and Sakhalin Energy Investment Company, Yuzhno-Sakhalinsk, Russia.

\section{References}

Altmann, J. (1974). Observational study of behaviour, sampling methods. Behaviour, 49, 227-267.

Batschelet, E. (1980). Circular statistics in biology. New York: Academic.

Borisov, S. V., Gritsenko, A. V., Jenkerson, M. R., Rutenko, A. N., \& Hodzevich, A.V. (2002). Evaluating and monitoring acoustic transmission from the Odoptu 3D seismic survey, 5 August-9 September, 2001, Report by V.I. Il'icev Pacific Oceanological Institute, Far East Branch, Russian Academy of Sciences, Vladivostok, and ExxonMobil Upstream Research Company, Houston, Texas, for Exxon Neftegas Limited, Yuzhno-Sakhalinsk, Russia.

Buckland, S. T., \& Breiwick, J. M. (2002). Estimated trends in abundance of eastern gray whales from shore counts, $1967 / 68$ to 1995/96. Journal of Cetacean Research and Management, 4(1), 41-48.

Cain, M. L. (1989). The analysis of angular data in ecological field studies. Ecology, 70, 1540-1543.

Darling, J. D. (1984). Gray whales off Vancouver Island, British Columbia. In M. L. Jones, S. L. Swartz, \& S. Leatherwood (Eds.), The gray whale, Eschrichtius robustus (pp. 267-287). New York: Academic.

Dunham, J. S., \& Duffus, D. A. (2002). Diet of gray whales (Eschrichtius robustus) in Clayoquot Sound, British Columbia, Canada. Marine Mammal Science, 18, 419-437.

Fadeev, V. I. (2002). Benthos studies in the feeding grounds of the Okhotsk-Korean gray whale population. Final report of 
the Marine Biology Institute of the Far East Branch of the Russian Academy of Science. Vladivostok.

Fadeev. V. I. (2003). Benthos and prey studies in feeding grounds of the Okhotsk-Korean population of gray whales. Vladivostok, Russia: Marine Biology Institute (The Far East Branch), Russian Academy of Sciences.

Gailey, G. A., \& Ortega-Ortiz, J. (2002). A note on a computerbased system for theodolite tracking of cetaceans. Journal of Cetacean Research Management, 4(2), 213-218.

Hatler, D. F., \& Darling, J. D. (1974). Recent observations of the gray whale in British Columbia. Canadian FieldNaturalist, 88, 449-459.

Hilton-Taylor, C. (2000). IUCN red list of threatened species, 2000. Gland, Switzerland: IUCN/SSC.

Johnson, S. (2002). Marine mammal mitigation monitoring program for 2001 Odoptu 3-D Seismic Survey, Sakhalin Island, Russia, Executive Summary. Prepared by LGL limited for Exxon-Neftegas Ltd. Yuzhno-Sakhalinsk, Russian Federation. IWC Working Paper \#SC/02/WGW19.

Johnson, S. R., Richardson, W. J., Yazvenko, S. B., Blokhin, S. A., Gailey, G., Jenkerson, M. R., et al. (2007). A western gray whale mitigation and monitoring program for a 3-D seismic survey, Sakhalin Island, Russia. Environmental Monitoring and Assessment, in press.

LeDuc, R. G., Weller, D. W., Hyde, J., Burdin, A. M., Rosel, P. E., Brownell, R. L., Jr., et al. (2002). Genetic differences between western and eastern gray whales (Eschrichtius robustus). Journal of Cetacean Research Management, 4, 1-5.

Ljungblad, D. K., Würsig, B., Swartz, S. L., \& Keene, J. M. (1988). Observations on the behavioral responses of Bowhead Whales (Balaena mysticetus) to active geophysical vessels in the Alaskan Beaufort Sea. Arctic, 41, 183-194.

Malme, C. I., \& Miles, P. R. (1985). Behavioral responses of marine mammals (gray whales) to seismic discharge. In G. D. Greene, F. R. Engelhardt, \& R. J. Paterson (Eds.), Proc. Workshop on effects of explosives use in the marine environment, Jan 1985 (pp. 253-280). Tech. Rep. 5. Can. Oil and Gas Lands Adm., Inviron. Prot. Br.

Malme, C. I., Würsig, B., Bird, J. E., \& Tyack, P. (1986). Behavioral responses of gray whales to industrial noise: feeding observations and predictive modeling. Outer Continental Shelf Environmental Assessment Program, Final report of Principal Investigators, NOAA, Anchorage, AK 56(1988): 393-600. BBN Report 6265.

Malme, C. I., Würsig, B., Bird, J. E., \& Tyack, P. (1987). Observations of feeding gray whale responses to controlled industrial noise exposure. In W. M. Sackinger \& M. O Jefferies (Eds.), Port and ocean engineering under Arctic conditions, vol. 2, symposium on noise and marine mammals (pp. 55-73). Fairbanks, AK: The Geophysical Institute, University of Alaska.

Martin, B., \& Bateson, P. (1993). Measuring behaviour (2nd ed.). New York: Cambridge University Press.

McCauley, R. D., Jenner, M-N., Jenner, C., McCabe, K. A., \& Murdoch, J. (1998). The response of humpback whales (Megaptera novaeangliae) to offshore seismic survey noise: Preliminary results of observations about a working seismic vessel and experimental exposures. APPEA Journal, 1998, 692-707.

McCauley, R. D., Fewtrell, J., Duncan, A. J., Jenner, C., Jenner, M. N., Penrose, J. D., et al. (2000). Marine seismic surveys - A study of environmental implications. APPEA Journal, 40, 692-708.

McCullagh, P., \& Nelder, J. A. (1989). Generalized linear models (2nd ed.). London: Chapman and Hall.

McDonald, T. L., Erickson, W. P., \& McDonald, L. L. (2000). Analysis of count data from before-after control-impact studies. Journal of Agricultural, Biological, and Environmental Statistics, 3, 262-279.

Meier, S., Lawson, J., Yazvenko, S., Perlov, A., Maminov, M., Johnson, S. R., et al. (2002). Vessel-based marine mammal monitoring during the 2001 3-D seismic survey of the Odoptu block, northeast Sakhalin Island, Okhotsk Sea, Russia. Final report by LGL Limited, Sidney BC, for Exxon Neftegas Limited, YuzhnoSakhalinsk, Russia.

Meier, S. K., Yazvenko, S. B., Blokhin, S. A., Wainwright, P., Maminov, M. K., Yakovlev, Y. M. et al. (2007). Distribution and abundance of western gray whales off northeast Sakhalin Island, Russia, 2001-2003. Environmental Monitoring and Assessment, in press.

Moore, S. E., \& Clarke, J. T. (2002). Potential impact of offshore human activities on gray whales (Eschrichtius robustus). Journal of Cetacean Research Management, 4, 19-25.

Moran, P. A. P. (1950). Notes on continuous stochastic phenomena. Biometrika, 37, 17-23.

Neter, J., Wasserman, W., \& Kutner, M. H. (1985). Applied linear statistical models: regression, analysis of variance, and experimental designs (2nd ed.). Homewood, IL: Irwin

Pike, G. C. (1962). Migration and feeding of the gray whale (Eschrichtius gibbosus). Journal of the Fisheries Research Board of Canada, 19, 815-838.

Ramsey, F., \& Schafer, D. (1997). The Statistical Sleuth. Duxbery, Belmont, CA.

Reeves, R. R., Ljungblad, D. K., \& Clarke, J. T. (1984). Bowhead whales and acoustic seismic surveys in the Beaufort Sea. Journal of Acoustical Society of America, $62,271-280$.

Richardson, W. J., Greene, C. R., Malme, C. I., \& Thompson, D. H. (1995). Marine mammal and noise. San Diego, CA: Academic.

Richardson, W. J., Miller, G. W., \& Greene, C. R. (1999). Displacement of migrating bowhead whales by sounds from seismic surveys in shallow waters of the Beaufort Sea. Journal of the Acoustical Society of America, 106, 2281.

Richardson, W. J., \& Würsig, B. (1997). Influences of manmade noise and other human actions on cetacean behavior. Marine and Freshwater Behaviour and Physiology, 29, 183-209.

Richardson, W. J., Würsig, B., \& Greene, C. R. (1986). Reactions of Bowhead whales, Balaena mysticetus, to seismic exploration in the Canadian Beaufort Sea. Journal of the Acoustical Society of America, 79, 1117-1128.

Rutenko, A. N., Borisov, S. V., Gritsenko, A. V. \& Jenkerson, M. R. (2007). Calibrating and monitoring the mitigation zone and estimating acoustic transmission for the 2001 Odoptu 3D seismic survey. Environmental Monitoring and Assessment, in press.

Smultea, M. A., \& Würsig, B. (1995). Behavioral reactions of bottlenose dolphins to the Mega Borg oil spill, Gulf of Mexico 1990. Aquatic Mammals, 21(3), 171-181. 
Sobolevsky, E. I. (2000). Marine mammal studies offshore northeast Sakhalin, 1999. Report by the Institute of Marine Biology, Far East Branch of Russian Academy of Sciences, Vladivostok, Russia, for Sakhalin Energy Investment Company, Yuzhno-Sakhalinsk, Russia, $149 \mathrm{p}$.

Sobolevsky, E. I. (2001). Marine mammal studies offshore northeast Sakhalin, 2000. Report by the Institute of Marine Biology, Far East Branch of Russian Academy of Sciences, Vladivostok, Russia, for Sakhalin Energy Investment Company, Yuzhno-Sakhalinsk, Russia, 199 p.

Turchin, P. (1998). Quantitative analysis of movement. Sunderland, MA: Sinauer Associates.

Venables, W. N., \& Ripley, B. D. (1994). Modern applied statistics in S-plus. New York: Springer.

Weller, D. W., Burdin, A. M., Bradford, A. L., Ivashchenko, Y. V., Tsidulko, G. A., Lang, A. R., et al. (2004). Western gray whales off Sakhalin Island, Russia: A joint USRussian scientific investigation July-September 2003. Report by National Marine Fisheries Service, National Oceanic and Atmospheric Administration, Southwest Fisheries Science Center, La Jolla, California, Kamchatka Branch of Pacific Institute of Geography, Far East Division, Russian Academy of Sciences, Petropovlovsk, Kamchatka, Russia, and Alaska Sealife Center, Seward, Alaska. 41 p.

Weller, D. W., Burdin, A. M., Würsig, B., Taylor, B. L., \& Brownell, R. L., Jr. (2002a). The western gray whale: a review of past exploitation, current status and potential threats. Journal of the Cetacean Research Management, 4, 7-12.

Weller, D. W., Ivashchenko, Y. V., Tsidulko, G. A., Burdin, A. M., \& Brownell, R. L., Jr. (2002b). Influence of seismic surveys on western gray whales off Sakhalin Island, Russia in 2001. Paper SC/54/BRG14 submitted to the International Whaling Commission.

Weller, D. W., Reeve, S. H., Burdin, A. M., Würsig, B., \& Brownell, R. L., Jr. (2002c). A note on the spatial distribution of western gray whales (Eschrichtius robustus) off Sakhalin Island, Russia in 1998. Journal of Cetacean Research Management, 4, 13-17.

Weller, D. W., Würsig, B., Bradford, A. L., Burdin, A. M., Blokhin, S. A., Minakuchi, H., et al. (1999). Gray whales (Eschrichtius robustus) off Sakhalin Island, Russia:
Seasonal and annual occurrence patterns. Marine Mammal Science, 15, 1208-1227.

Würsig, B., Cipriano, F., \& Würsig, M. (1991). Dolphin movement patterns: information from radio and theodolite tracking studies. In K. Pryor \& K. S. Norris (Eds.), Dolphin Societies - Discoveries and puzzles (pp. 79-112). Los Angeles, CA: University of California Press.

Würsig, B., Gailey, G., McDonald, T., Nielson, R., OrtegaOrtiz, J. G., Wainwright, P., et al. (2002). Western gray whale occurrence patterns and behavior: Shore-based observations off Sakhalin Island, August-September 2001. Final report for Exxon Neftegas Limited, YuzhnoSakhalinisk, Russia.

Würsig, B., Weller, D., Burdin, A., Blokhin, S., Reeve, S., Bradford, A., et al. (1999). Gray whales summering off Sakhalin Island, Far East Russia: July-October 1997. A joint US-Russian scientific investigation. Final Contract Report to Sakhalin Energy Investment Company and Exxon Neftegas (unpublished), $101 \mathrm{pp}$.

Würsig, B., Wells, R. S., \& Croll, D. A. (1986). Behavior of gray whales summering near St. Lawrence Island, Bering Sea. Canadian Journal of Zoology, 64, 611-621.

Yakovlev, Y., \& Tyurneva, O. (2005). Photo-identification of the Korea-Okhotsk gray whale (Eschrichtius robustus) population on the Northeast shelf of Sakhalin Island, Russia 2004. Final report to Exxon Neftegas and Sakhalin Energy Investment Company, Yuzhno-Sakhalinsk, Russia, 82 p.

Yazvenko, S., MacDonald, T., Meier, S., Blokhin, S., Johnson, S. R., Vladimirov, V., et al. (2002). Aerial marine mammal monitoring during the 2001 3-D seismic survey of the Odoptu Block, northeast Sakhalin Island, Okhotsk Sea, Russia. Final report by LGL Limited, Sidney, BC, for Exxon Neftegas Limited, Yuzhno-Sakhalinisk, Russia.

Yazvenko, S. B., MacDonald, T., Blokhin, S. A., Johnson, S. R., Nielson, R., Vladimirov, V.L., et al. (2007a). Distribution and abundance of western gray whales in the Piltun feeding area, northeast Sakhalin Island, Russia. Environmental Monitoring and Assessment, (this issue).

Yazvenko, S. B., MacDonald, T., Blokhin, S. A., Johnson, S. R., Nielson, R., Vladimirov, V.L., et al. (2007b). Feeding of western gray whales during a seismic survey near Sakhalin Island, Russia. Environmental Monitoring and Assessment, (this issue). 